\title{
Pain Management and Nursing Approaches in Pediatric Oncology
}

\author{
Nejla Canbulat ${ }^{1}$ and Ayşe Sonay Kurt ${ }^{2}$ \\ ${ }^{1}$ Karamanoglu Mehmetbey University, \\ Karaman School of Health, Karaman, \\ ${ }^{2}$ Selcuk University, Faculty of Health Science, Konya, \\ Turkey
}

\section{Introduction}

Pain is defined as "an unpleasant sensory and emotional experience associated with actual or potential tissue damage, or described in terms of such damage (Higginson\&Murtagh 2010). Defining "pain" in a succinct manner is a great challenge. What is pain? It has been described as an emotional state, a physical experience, a spiritual sacrament, and a complex set of interconnected subcellular signals (Mirchandani et al., 2011). According to the International Association for the Study of Pain (IASP), pain is defined as "an unpleasant sensory and emotional experience which we primarily associate with tissue damage or describe in terms of such damage, or both (Portenoy\&Kanner 1996). In different places and in different points over time, both Eastern and Western medical traditions have included a concept of imbalance as an important etiology of painful symptoms (Helms, 1998) ... the difference between the body of a living man and that of a dead man is just like the difference between (Bias\&Cope, 2011). Cancer pain may be either acute or chronic. Acute pain; acute pain is initially treated with short-acting non-opioid pharmacologic agents or combination opioid drugs. Acute versus chronic pain is important to clearly differentiate. Acute pain is rapid in onset, self-limiting, a symptom of the disease, and the patient often presents in acute distress. Examples of acute pain include postoperative pain, obstetrical labor pain, and trauma or injury-related pain and characteristically is described as sudden, sharp, and localized pain. It is usually self-limited and may be associated with physiologic changes such as diaphoresis and increases in heart rate and blood pressure (Mirchandani et al 2011). Chronic pain; chronic pain is long-term pain classified as acute, moderate, and severe. It is often differentiated as malignant or non-malignant pain. Chronic pain is often described as gnawing, aching, and diffuse and is more gradual in onset and cessation than acute pain, which can also be simultaneously superimposed on top of the former. It can vary in intensity, may remit briefly, and has definite impact psychologically and socially. Pain characteristics: Acute and chronic was given Table 1. The treatment for such pain is often successful with traditional pharmacologic measures; however, often less traditional drugs and even non-pharmacologic therapies are necessary to achieve relief (Mirchandani et al., 2011). 


\begin{tabular}{|l|l|}
\hline Acute pain & Chronic pain \\
\hline 1. Usually obvious tissue damage & 1. Multiple causes (malignancy, benign) \\
2. Distinct onset & 2. Gradual or distinct onset \\
3. Short, well-characterized duration & 3. Persists after 3-6 months of healing \\
4. Resolves with healing & 4. Can be a symptom or diagnosis \\
5. Serves a protective function & 5. Serves no adaptive purpose \\
6. Effective therapy is available & 6. May be refractory to treatment \\
\hline
\end{tabular}

Table 1. Pain characteristics: acute and chronic (Mirchandani et al., 2011)

Over time and across cultures, the understanding and expression of pain reflects the contemporary spirit of the age. Universally, the human experience begins through the painful process of birth, and throughout our lifetimes (Dedeli\&Karadeniz, 2009). Factors mediating children's pain was given Fig. 1.

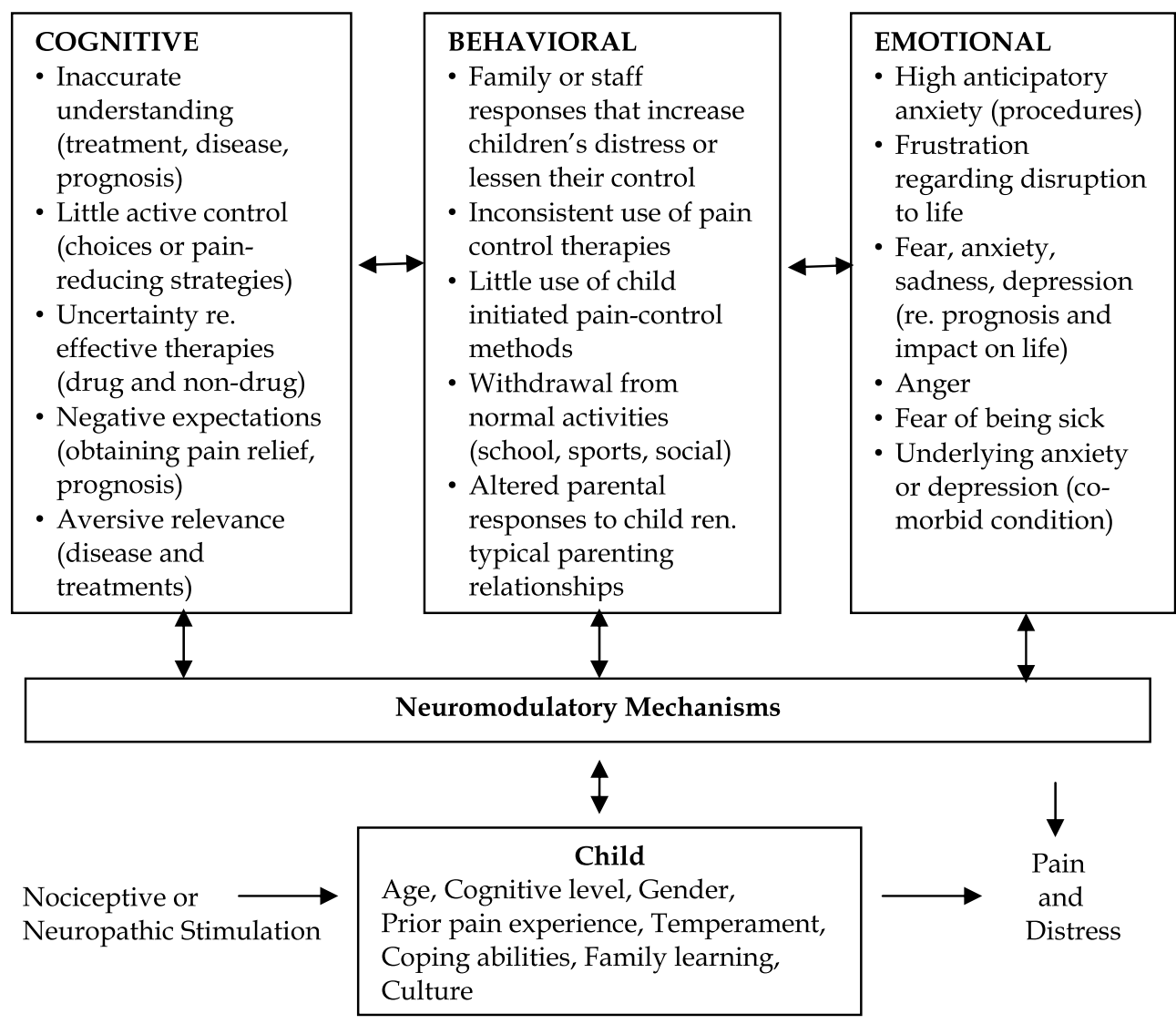

Fig. 1. Situational factors mediating children's pain (McGrath\&Crawford, 2010) 
Physiologic pain is defined as rapidly perceived non-traumatic discomfort of very short duration, alerting the individual of a dangerous stimulus. This is adaptive and initiates the withdrawal reflex that prevents and/or minimizes tissue injury. Physiologic pain can be divided into neuropathic pain and nociceptive pain (Mirchandani et al., 2011). Physiologic pain types of pain was given Table 2 .

\begin{tabular}{|c|c|}
\hline \multicolumn{2}{|r|}{ Two Major Types of Pain } \\
\hline I. Nociceptive Pain & II. Neuropathic Pain \\
\hline $\begin{array}{l}\text { A. Somatic Pain } \\
\text { B. Visceral Pain }\end{array}$ & $\begin{array}{l}\text { A. Centrally Generated Pain } \\
\text { B. Peripherally Generated Pain }\end{array}$ \\
\hline $\begin{array}{l}\text { I. Nociceptive Pain: Normal } \\
\text { process of stimuli that damages } \\
\text { normal tissues or has the } \\
\text { potential to do so if prolonged; } \\
\text { usually responsive to non- } \\
\text { opioids and/or opioids. } \\
\text { A. Somatic Pain: Arises from } \\
\text { bone, joint, muscle, skin, or } \\
\text { connective tissue. It is usually } \\
\text { aching or throbbing in quality } \\
\text { and is well localized. } \\
\text { B. Visceral Pain: Arises from } \\
\text { visceral organs, such as the GI } \\
\text { tract and pancreas. This may be } \\
\text { subdivided: } \\
\text { 1. Tumor involvement of the } \\
\text { organ capsule that causes } \\
\text { aching and fairly well-localized } \\
\text { pain. } \\
\text { 2. Obstruction of hollow viscus, } \\
\text { which causes intermittent } \\
\text { cramping and poorly localized } \\
\text { pain. }\end{array}$ & $\begin{array}{l}\text { II. Neuropathic Pain: Abnormal processing of sensory } \\
\text { input by the peripheral or central nervous system; } \\
\text { treatment usually includes adjuvant analgesics. } \\
\text { A. Centrally Generated Pain } \\
\text { 1. Deafferentation pain: Injury to either the peripheral } \\
\text { or central nervous system. Examples: Phantom pain } \\
\text { may reflect injury to the peripheral nervous system; } \\
\text { burning pain below the level of a spinal cord lesion } \\
\text { reflects injury to the central nervous system. } \\
\text { 2. Sympathetically maintained pain: Associated with } \\
\text { dysregulation of the autonomic nervous system. } \\
\text { Examples: May include some of the pain associated } \\
\text { with reflect sympathetic dystrophy/causalgia } \\
\text { (complex regional pain syndrome, type I, type II). } \\
\text { B. Peripherally Generated Pain } \\
\text { 1. Painful polyneuropathies: Pain is felt along the } \\
\text { distribution of many peripheral nerves. Examples: } \\
\text { diabetic neuropathy, alcohol-nutritional neuropathy, } \\
\text { and those associated with Guillain-Barre syndrome. } \\
\text { 2. Painful mononeuropathies: Usually associated with } \\
\text { a known peripheral nerve injury, and pain is felt at } \\
\text { least partly along the distribution of the damaged } \\
\text { nerve. Examples: nerve root compression, nerve } \\
\text { entrapment, trigeminal neuralgia. }\end{array}$ \\
\hline
\end{tabular}

Table 2. Physiologic pain types

The four predominant etiologies of cancer pain are: (1) that directly produced by the tumor; (2) that due to the various modalities of cancer therapy; (3) that related to chronic debility; and (4) that due to an unrelated, concurrent disease process (Eidelman\&Carr, 2006). TumorRelated Pain; Most cancer-related pain is directly produced by the malignancy itself. The neoplasm may extend into surrounding tissue and exert pressure on nociceptors in diverse organs, as well as nerves. Furthermore, recent studies have found evidence that pain-gene rating mediators are directly released from certain tumors or from surrounding tissue in response to tumor invasion or metastasis such as to bone (Eidelman\&Carr, 2006; Unuvar, 1999). Treatment-Related Pain; The various modalities of cancer therapy may paradoxically cause pain. Cancer patients may experience acute discomfort following surgery or other 
invasive procedures. Also, there are numerous postsurgical chronic pain syndromes. The administration of chemotherapy itself may cause immediate acute pain (e.g., intravenous infusion pain, abdominal discomfort during intraperitoneal infusion) or painful sequelae such as mucositis, arthralgias, and headaches. Moreover, chemotherapeutic agents, including vinca alkaloids, cisplatin, and paclitaxel, are associated with peripheral neuropathies. Radiation therapy may injure soft tissue or neuronal structures, resulting in mucositis, proctitis, enteritis, osteonecrosis, peripheral neuro pathies, or plexo pathies. Furthermore, novel anti cancer agents such as hormonal or immunotherapy may produce pain (Eidelman\&Carr, 2006; Unuvar, 1999). Debility-Related Pain; Many cancer patients may be inactive or suffer debilities that are associated with painful conditions. Many cancer patients may be inactive or suffer debilities that are associated with painful conditions. For instance, patients who have received immunosuppressive therapy or have hematologic malignancies are at increased risk for developing postherpetic neuralgia. Also, many malignancies are associated with an increased incidence of thrombosis, which may present as pain and swelling in the affected site (Eidelman\&Carr, 2006). Non-Malignant Concurrent Disease; Patients with cancer may experience discomfort as a direct consequence of a concurrent, benign disease process (e.g., degenerative joint disease or diabetic neuropathy). Therefore, it is important to review patients' past medical histories and to consider any coexisting nonmalignant condition as a potential source of symptoms (Eidelman\&Carr 2006).

\section{Epidemiology}

\subsection{Frequency}

World Health Organization (WHO ) states that 25\% of cancer patients suffer pain, 33\% of such patients suffer pain during treatment of the diseases, the rate of pain is between $75-90 \%$ in advanced and terminal period of the disease, $70 \%$ of such pain is directly associated with cancer, $20 \%$ of such pain is also based on cancer treatment (Aslan, 2006).

When pain reasons of the patients consulted with a algology clinic in Turkey were analyzed, it was found that cancer pain ranked the first (Aslan, 2006). The prevalence of cancer pain in patients with advanced or terminal disease was given Table 3.

Even when WHO guidelines are followed, failure to achieve satisfactory pain relief occurs in $10 \%-20 \%$ of patients. For these instances, some authors have proposed descriptors such as "opioid-poorly responsive pain" or "opioid-irrelevant pain." Therefore, there is a need both in clinical practice and in the standardized comparison of research findings for a systematic approach to identify and categorize factors associated with a poor prognosis $\left(\mathrm{O}^{\prime}\right.$ leary et al., 2010).

\subsection{Pain assessment methods}

Pain assessment and pain measurement in children is challenging. These challenges depend on permanent changes in process of child's perception, interpretation and expression with regards to age, growth phase, previous pain experience and other environmental factors (Manworren\&Hynan, 2003; Unuvar, 1999). Pain assessment in children is given in the fig. 2 (Ramamurthy, 2006) 


\begin{tabular}{|c|c|c|c|c|}
\hline Study type & $\begin{array}{l}\text { Disease definition and } \\
\text { tumor type }\end{array}$ & $\begin{array}{l}\text { Sample } \\
\text { size }\end{array}$ & Prevalence & Reference \\
\hline \multirow[t]{2}{*}{$\begin{array}{l}\text { Retrospective } \\
\text { study }\end{array}$} & $\begin{array}{l}\text { Caregivers of general } \\
\text { cancer population }\end{array}$ & 170 & \begin{tabular}{|l|}
$-86 \%$ stated pain was a \\
problem, $61 \%$ \\
reported a great deal or quite a \\
bit of pain, $25 \%$ had some or \\
little pain
\end{tabular} & $\begin{array}{l}\text { Bucher et } \\
\text { al., } 1999\end{array}$ \\
\hline & & & \begin{tabular}{|l} 
- $82 \%$ reported data on pain \\
relief \\
intervention, $46 \%$ of which \\
made pain \\
stop/get better, $56 \%$ of which \\
made pain a little better or had \\
no effect or made it worse
\end{tabular} & \\
\hline $\begin{array}{l}\text { Prospective } \\
\text { study }\end{array}$ & $\begin{array}{l}\text { Advanced cancer } \\
\text { patients } \\
\text { admitted to hospice }\end{array}$ & 232 & $\begin{array}{l}-81 \% \text { had pain at the time of } \\
\text { admission } \\
\text { - Pain severity worsened in the } \\
48 \text { hours } \\
\text { before death (prevalence not } \\
\text { reported) }\end{array}$ & $\begin{array}{l}\text { Chiu et } \\
\text { al., } 2000\end{array}$ \\
\hline $\begin{array}{l}\text { Retrospective } \\
\text { case note } \\
\text { review }\end{array}$ & $\begin{array}{l}\text { Patients referred to } \\
\text { palliative care } \\
\text { services - hospice, } \\
\text { community, } \\
\text { hospital, and } \\
\text { outpatient (95\% with } \\
\text { cancer; of } \\
\text { these, } 71 \% \text { had } \\
\text { advanced disease) }\end{array}$ & 400 & \begin{tabular}{|l|} 
- $64 \%$ had pain at first \\
assessment \\
- In the hospice, $62 \%$ of \\
patients had pain \\
- In the community setting, \\
$56 \%$ had pain \\
- In the hospital service, $63 \%$ \\
had pain \\
- In the outpatient service, $75 \%$ \\
had pain
\end{tabular} & $\begin{array}{l}\text { Potter et } \\
\text { al., } 2003\end{array}$ \\
\hline $\begin{array}{l}\text { Cross-sectional } \\
\text { survey }\end{array}$ & $\begin{array}{l}\text { Patients with } \\
\text { metastatic cancer or } \\
\text { stage IV lymphoma in } \\
\text { hospital for } 72 \text { hours } \\
\text { for complications } \\
\text { not treatment } \\
\end{array}$ & 66 & $\begin{array}{l}-78 \% \text { of patients had pain } \\
\text { (assessed using the Memorial } \\
\text { Symptom Assessment Scale) }\end{array}$ & $\begin{array}{l}\text { Tranmer } \\
\text { et al., } \\
2003\end{array}$ \\
\hline $\begin{array}{l}\text { Prospective } \\
\text { survey }\end{array}$ & $\begin{array}{l}\text { In- and outpatients } \\
\text { with } \\
\text { metastatic or } \\
\text { recurrent cancer }\end{array}$ & 655 & $\begin{array}{l}-70.8 \% \text { had some pain in the } \\
\text { previous } 24 \text { hours } \\
-63.3 \% \text { rated their pain at } 5 \text { or } \\
\text { higher on a visual analogue } \\
\text { scale of } 0-10\end{array}$ & $\begin{array}{l}\text { Yun et } \\
\text { al., } 2003\end{array}$ \\
\hline
\end{tabular}

Table 3. The prevalence of cancer pain in patients with advanced or terminal disease, or who are at the end of life 


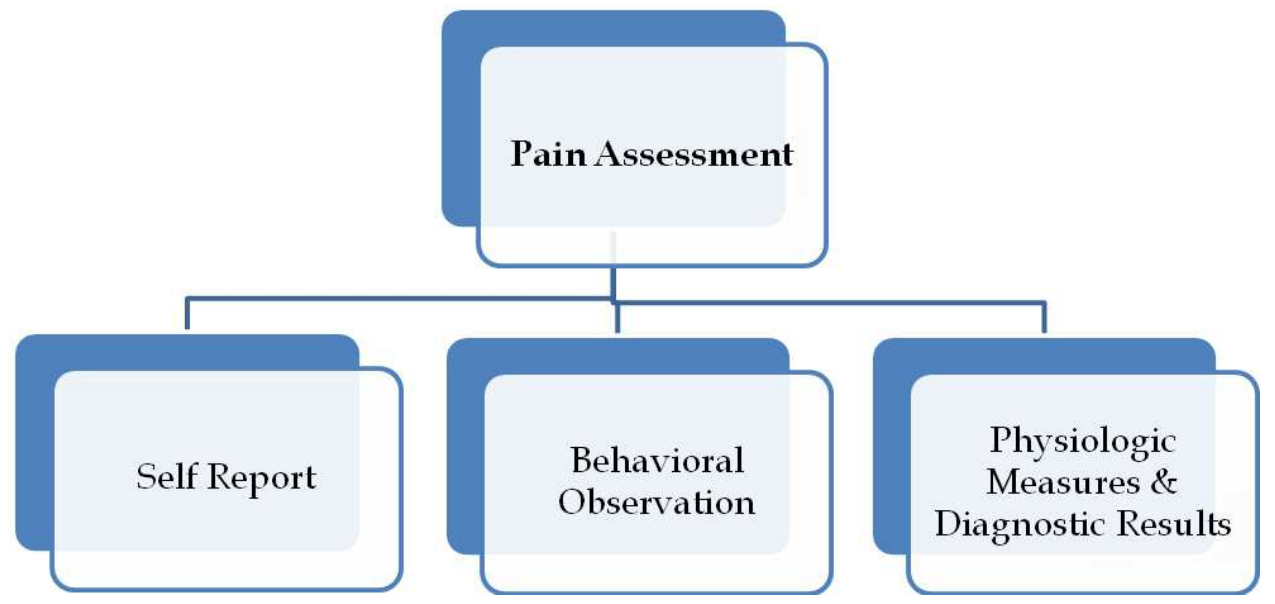

Fig. 2. Pain assesment stages (Hockenberry-Eaton et al., 1999)

The "ABCs" of pain assessment in children are:

- Assess: Always evaluate a child with cancer for potential pain. Children may experience pain, even though ther may be unable to expree the fact in words. Infans and toddlers can show their pain only by how they look and act: older children may deny their pain for fear of more painful treatment.

- Body: Be careful to consider pain as an integral part of the physical examination. Physical examination should include a comprehensive check of all body areas for potential pain sites. The child's reactions during the examination-grimacing, contracture, rigidity, etc.- may indicate pain.

- Context: Consider the impact of family, health-care, and environmental factors on the child's pain.

- Document: Record the severity of a child's pain on a regular basis. Use a pain scale that is simple and appropriate both for the developmental level of the child and fort he cultural context in which it is used.

- Evaluate: Assess the effectiveness of pain interventions regularly and modify the treatment plan as necessary, until the child's pain is alleviated or minimized.

Selection of method to be used for pain assessment in children should be made considering child's age, general status, pain recognition (Manworren\&Hynan, 2003; Unuvar, 1999). Children show their pains in different ways according to age group. Newborn children move less than normal, cry more frequently and are highly restless, may look pale and sweaty when they have pain. They do not eat as much as they eat normally. They cry if they are touched or moved (Manworren\&Hynan, 2003). Toddler; painful toddler may cry more than normal, is restless and moves less than normal like newborn children. Toddler may show location of the pain even though it may not state explicitly when she/he has pain. When toddlers are spoken about the pain, they may understand this. Do not think that you have known your child's pain location. In a study carried out, it is claimed that "FLACC" (Face ,Legs, Activity, Cry, Consolability) pain assessment scale which is conducted by assessing child's facial express, position of legs, movements, crying and being relieved is quite useful in paediatric nurse's assessing pain and pain approach in preverbal patients. In 
this study, patient's pains were graded with scores ranging between 0 to 10 by using "FLACC" score and the effects of oral and IV analgesics were evaluated. FLACC scores prior to use of analgesic drug were found significantly higher as compared to an assessment carried out subsequent to use of analgesic drug (Manworren\&Hynan, 2003). Young children; young children think of their pains until they are able to speak. Child may be asked about the location of the pain. Child should be given help to find the location of the pain. Child might be asked to paint the location of the pain by showing him a picture as indicated below (Fig. 3).

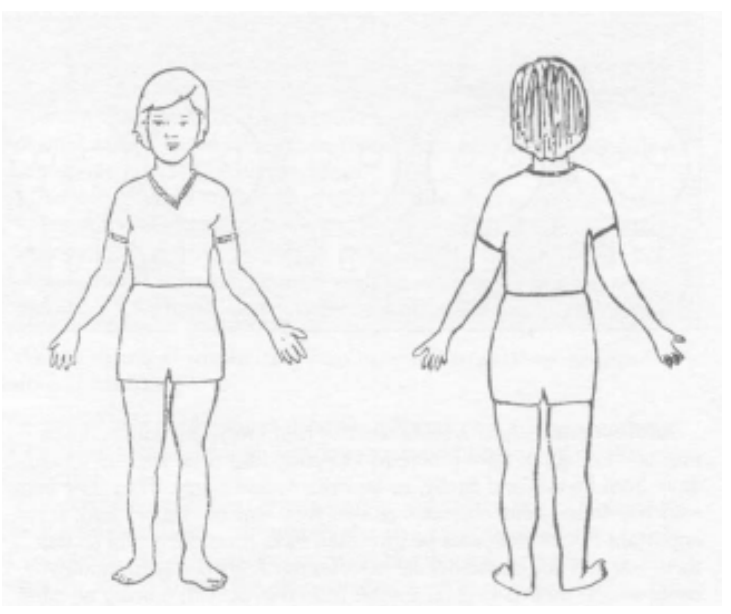

Fig. 3. Location of the pain in children

After determination of presence and location of the pain, it is required to determine the level of the pain. Pain might be measured with 3 different methods since it is subjective and individual (Fig. 2) (Unuvar, 1999). First of these methods is personal expressions. This method is the most important one in pain assessment which attempts to assess the cognitive component of the pain. It is necessary to know well the words which children use in describing the pain. The most frequently used method is face scale (Fig. 4) (HockenberryEaton et al., 1999).

Pain Scale

FACES Pain Rating Scale

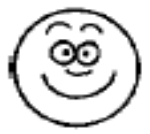

0

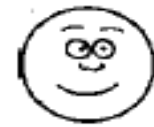

1

Hurts

\section{Descriptive}

Consists of six cartoon faces ranging from a smiling face for "no pain" to tearful face for "worst pain"

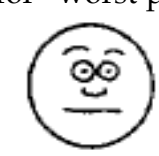

2

Hurts

Little More

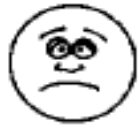

3

Hurts

Even More

\section{Recommended age}

Children as young as 3 years

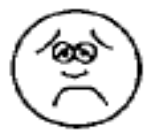

4

Hurts

Whole Lot

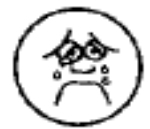

5

Hurts

Worst

Fig. 4. Face scale (Hockenberry-Eaton et al., 1999) 
The other methods depend on behaviour pattern (such as tone of voice, facial expression and gestures) and biological parameters (such as heart rate, falling of peripheral oxygen saturation). Personal expression is the best measurement method if can be obtained and is accepted as "golden rule" in pain measurement (Unuvar, 1999). Behavioral pain assessment scale for young children was given in the Table 4.

\begin{tabular}{|l|l|l|l|}
\hline \multicolumn{4}{|l|}{ FLACC Scale Scoring } \\
\hline Categories & 0 & 1 & 2 \\
\hline Face & $\begin{array}{l}\text { No particular } \\
\text { expression or smile }\end{array}$ & $\begin{array}{l}\text { Occasional grimace or } \\
\text { frown, withdrawn, } \\
\text { disinterested }\end{array}$ & $\begin{array}{l}\text { Frequent to constant } \\
\text { quivering chin, } \\
\text { clenched jaw }\end{array}$ \\
\hline Legs & $\begin{array}{l}\text { Normal position or } \\
\text { relaxed }\end{array}$ & Uneasy, restless, tense & $\begin{array}{l}\text { Kicking, or legs } \\
\text { drawn up }\end{array}$ \\
\hline Activity & $\begin{array}{l}\text { Lying quietly, normal } \\
\text { position, moves easily }\end{array}$ & $\begin{array}{l}\text { Squirming, shifting back } \\
\text { and forth, tense }\end{array}$ & $\begin{array}{l}\text { Arched, rigid or } \\
\text { jerking }\end{array}$ \\
\hline Cry & $\begin{array}{l}\text { No cry (awake or } \\
\text { asleep) }\end{array}$ & $\begin{array}{l}\text { Moans or whinpers; } \\
\text { occasional complaint }\end{array}$ & $\begin{array}{l}\text { Crying steadily, } \\
\text { screams or sobs, } \\
\text { frequent complaints }\end{array}$ \\
\hline Consolability & Content, relaxed & $\begin{array}{l}\text { Reassured by occasional } \\
\text { touching, hugging or } \\
\text { being talked to, } \\
\text { distractible }\end{array}$ & $\begin{array}{l}\text { Difficult to console or } \\
\text { comfort }\end{array}$ \\
\hline
\end{tabular}

Total is scored from $0-10$.

Table 4. Behavioral pain assessment scales for young children (Hockenberry-Eaton et al., 1999)

Adolescents; adolescents give reactions similar to adults. They may look calm, have sleeping problems, loss of appetite, avoid from friends or family, be nervous or angry. They may not say when they have pain since they are afraid of getting addicted to narcotics. The best method determine the pain of adolescent patients is scales which have assessment criteria ranging 0 to $5(0=$ presence of no pain, $5=$ presence of intense unbearable pain $)$. Expression of pain according to age groups was given Table 5 .

\section{Pain control methods}

The necessary nature of pain treatment has long been categorized among other basic human rights, and in 1999 the Joint Commission on Accreditation of Healthcare Organizations formalized pain standards to ensure to all patients their right to appropriate assessment and management of their pain, describing pain as the "fifth vital sign" (Lanser, 2001). Intrinsic to our capacity to treat pain is possession of perspective of themany cultural beliefs, philosophical ideologies, and scientific discoveries that have influenced and evolved into the modern Western conceptualization of pain. Cancer pain can not be treated sufficiently. In analysis of 11 reports including 2000 cancer patients in 1986, it was found that pains could not be healed in $50-80 \%$ of the patients in developed country. Pain may be healed with simple methods in $90 \%$ of cancer patients. However, it was also detected that pains could not be healed with acceptable methods in $10 \%$ of these patients. American National Cancer Institute attracted attention to be importance of issue with message that "being unable to treat cancer pain is a serious and unacceptable community health problem" (Aslan, 2006). 


\begin{tabular}{|c|c|}
\hline \begin{tabular}{|l|}
$\begin{array}{l}\text { Developmental } \\
\text { group }\end{array}$ \\
\end{tabular} & Expressions of pain \\
\hline Infants & $\begin{array}{l}\text { May: } \\
\text { Exhibit body rigidity or thrashing may include arching } \\
\text { Exhibit facial expression of pain (brows lowered and drawn together, } \\
\text { eyes, tightly closed, mouth open ans squarish) } \\
\text { Cry intensely/loudly } \\
\text { Be inconsolable } \\
\text { Draw knees to chest } \\
\text { Exhibit hypersensitivity or irritability } \\
\text { - Have poor oral intake } \\
\text { Be unable to sleep }\end{array}$ \\
\hline Toddlers & $\begin{array}{l}\text { May: } \\
\text { Be verbally aggressive, cry intensely } \\
\text { Exhibit regressive behavior or withdraw } \\
\text { Exhibit physical resistance by pushing painful stimulus away after it is } \\
\text { applied } \\
\text { Guard painful area of body } \\
\text { Be unable to sleep }\end{array}$ \\
\hline $\begin{array}{l}\text { Preschoolers/ } \\
\text { Young Children }\end{array}$ & $\begin{array}{ll}\text { May: } \\
- & \text { Verbalize intensity of pain } \\
- & \text { See pain as punishment } \\
- & \text { Exhibit thrashing of arms and legs } \\
\text { Attempt to push stimulus away before it is applied } \\
\text { - } & \text { Be uncooperative } \\
\text { - } & \text { Cling to physical restrain } \\
- & \text { Request emotional support (e.g. hugs, kisses) } \\
- & \text { Understand that there can be secondary gains associated with pain } \\
\text { Be unable to sleep }\end{array}$ \\
\hline $\begin{array}{l}\text { School-Age } \\
\text { Children }\end{array}$ & $\begin{array}{l}\text { May: } \\
-\quad \text { Verbalize pain } \\
\text { - } \\
\text { Bse an objective measurement of pain } \\
\text { - Experience nightmares related to pain } \\
\text { - } \\
\text { Exhibit stalling behaviors (e.g., "Wait a minute" or " I'm not ready") } \\
\text { Have muscular rigidity such as clenched first, white knuckles, gritted } \\
\text { teeth, contracted limbs, body stiffness, closed eyes, or wrinkled forehead } \\
\text { Include all behaviors of preschoolers/young children } \\
\text { Be unable to sleep }\end{array}$ \\
\hline Adolescents & $\begin{array}{ll}\text { May: } \\
-\quad \text { Localize and verbalize pain } \\
\text { - } & \text { Deny pain in presence of peers } \\
- & \text { Have changes in sleep patterns or appetite } \\
\text { - } & \text { Be influenced by cultural beliefs } \\
\text { - } & \text { Display muscle tension and body control } \\
- & \text { Be unable to sleep }\end{array}$ \\
\hline
\end{tabular}

Table 5. Expression of pain in children 
The WHO Analgesic Stepladder is a multi-step approach to treating pain, and is a guide for initiating analgesic drugs and dosages that correspond to the patient's reported level of pain (Fig. 5). The ladder starts with non-opioid oral drugs for mild pain and progresses to strong opioids, adjuvants and invasive therapies for severe and/or intractable pain (HockenberryEaton et al., 1999).

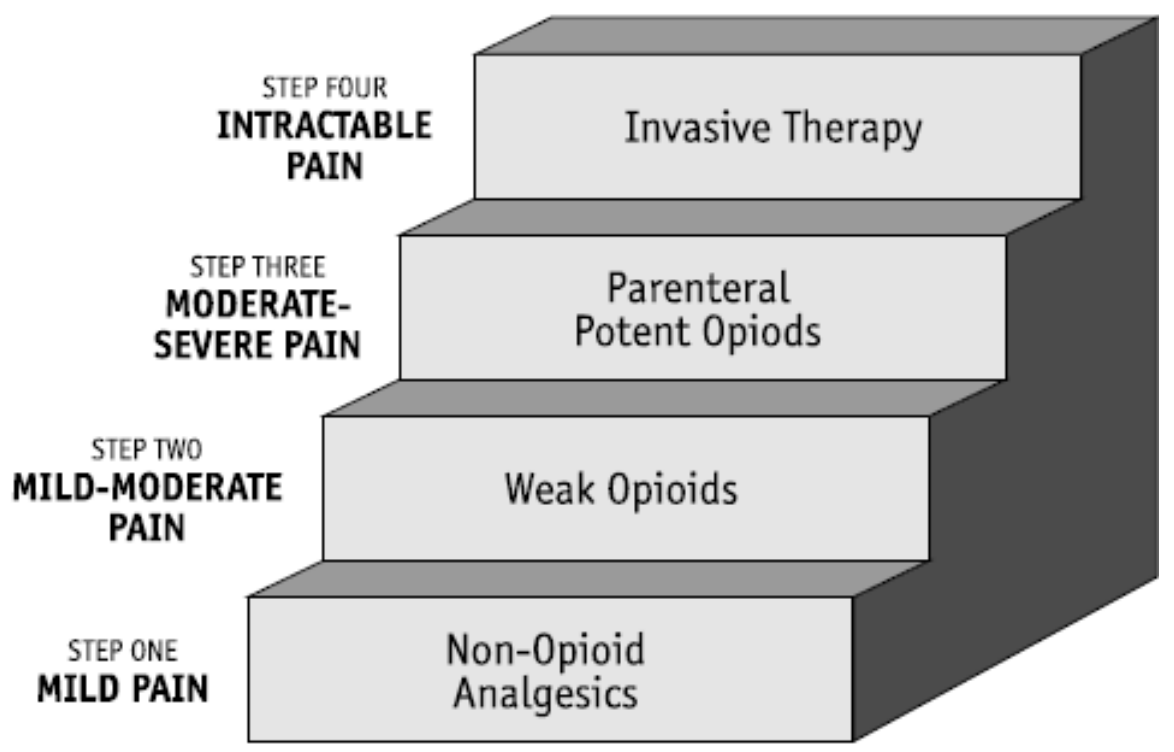

Fig. 5. Therpeutic ladder for pain management (Hockenberry-Eaton et al., 1999)

\subsection{Pharmacological pain management}

Western oncology group states that although cancer patients have taken analgesic, $67 \%$ of them have pain, $36 \%$ of them have so severe pains as to deteriorate their daily functions, $42 \%$ of them have not taken sufficient analgesic treatment. Tolerance and fear of addiction prevents cancer treatment (Aslan, 2006). While planning pain treatment, location, level, quality of pain, presence and features of the diseases causing pain, age of patient, present clinical facilities should be taken into consideration. In the light of all these features, treatment method is decided (Bedre\& Sethna, 2002; Krauss\& Gren, 2000). Drug treatment is the most frequently used method in treatment of acute and chronic pains in children. Analgesic drugs can be used singly or in a drug combination way (Golianu et al., 2000). For this purpose, non-opioid analgesics, opioid analgesics and adjuvant analgesics are used. In recent years, significant developments have been made in this field by adjustment of doses of these drugs and knowing their efficiency and pharmacologic differences in children. The most significant steps in this field have been taken by WHO. In consequence of studies concerning drug use especially in children with cancer pain, WHO published a guide book titled cancer pain treatment and palliative care (WHO, 1998). Medical management of cancer pain was given Fig. 6 . 
Evaluate pain

Exacerbating/remitting factors

Location, character, intensity

Pattern of radiiation, temporal factors, previous therapies

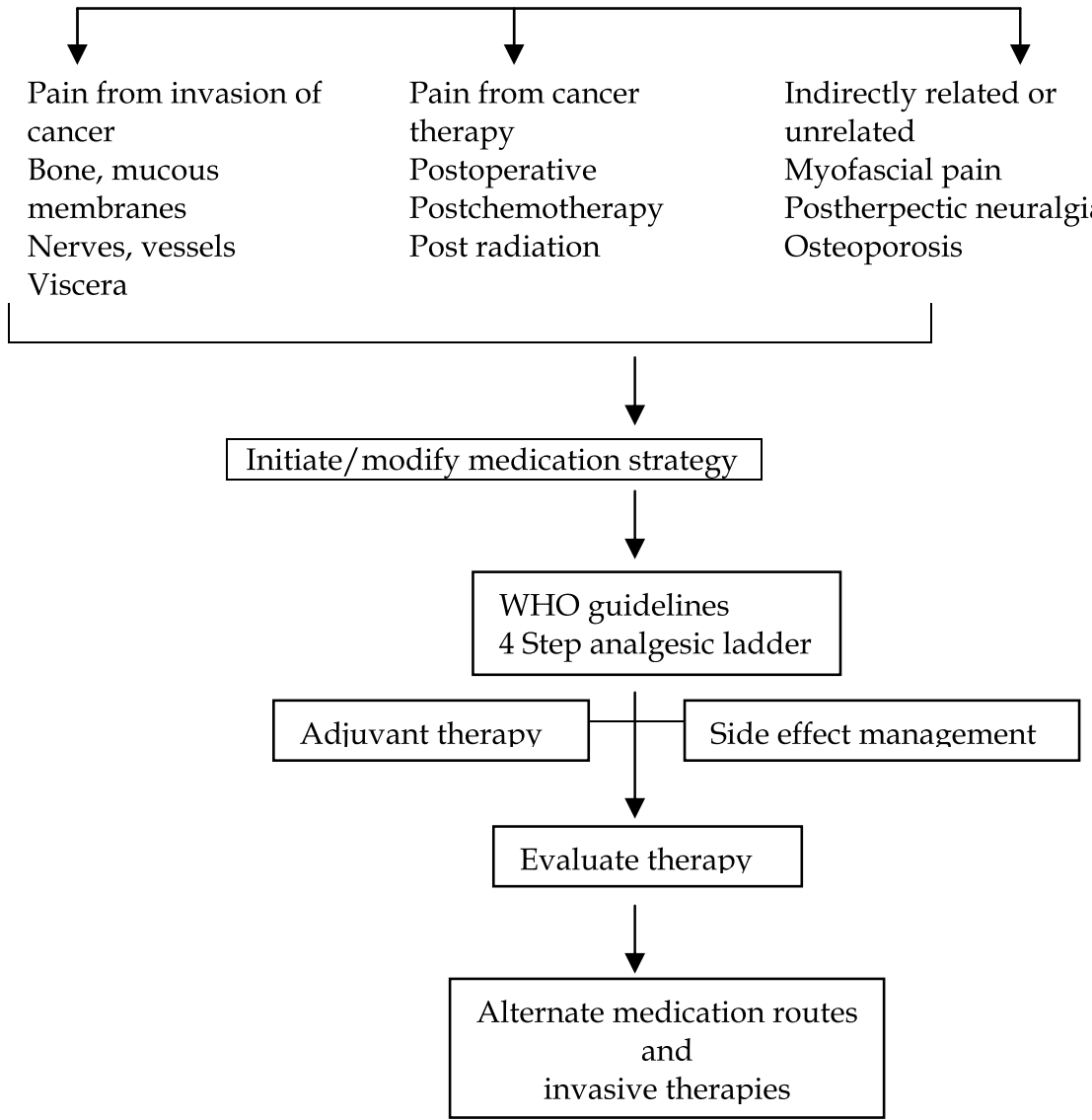

Fig. 6. Medical management of cancer pain (Gindrich, 2006)

\subsubsection{Opioid (narcotic) analgesics}

The word "opioid" contains all components associated with opium. Use of pure alkaloids has become widespread in whole world since second half of 19th century after Serturner isolated morphine from opium for the first time in 1806 (Cizmeci\& Babacan, 2007). The first preference should be oral route in implementation of analgesic drugs, which is the first pain control method in algorithms used in treatment of chronic pains. Where oral intake is not possible, intravenous, intramuscular, subcutaneous, transdermal, intrathecal, or epidural route might be used (Golianu et al., 2000). Opioids are used for removal of severe pains. Opioids such as morphine, meperidine, methadone, fentanyl, codeine and hydromorphone are included in this group and are the most frequent used morphines. Gradually increasing 
doses might be needed in order to prevent pain due to tolerance occurring against opioids. Tolerance and development of addiction dependent on morphine use occur in children less than in adults. Morphine, intravenous, intramuscular are used with oral route, while nasal, intratecal are used with epidural route (Bedre\& Sethna 2002).

The most commonly used 2 drugs;

- Morphine, given at 0,1 mg/kg IV 5-10 minutes before the procedure or $0,3 \mathrm{mg} / \mathrm{kg}$ orally 1 hour before the procedure.

- $\quad$ Fentanyl, 0.5-2 $\mu \mathrm{g} / \mathrm{kg}$ given 5-10 minutes before the procedure.

The combined use of opioids and benzodiazepines should be evaluated for for efficacy and for any potential adverse effects at the peak of their action to guide subsequent titration (WHO, 1998). Schema related to using opiods was given Fig. 7.

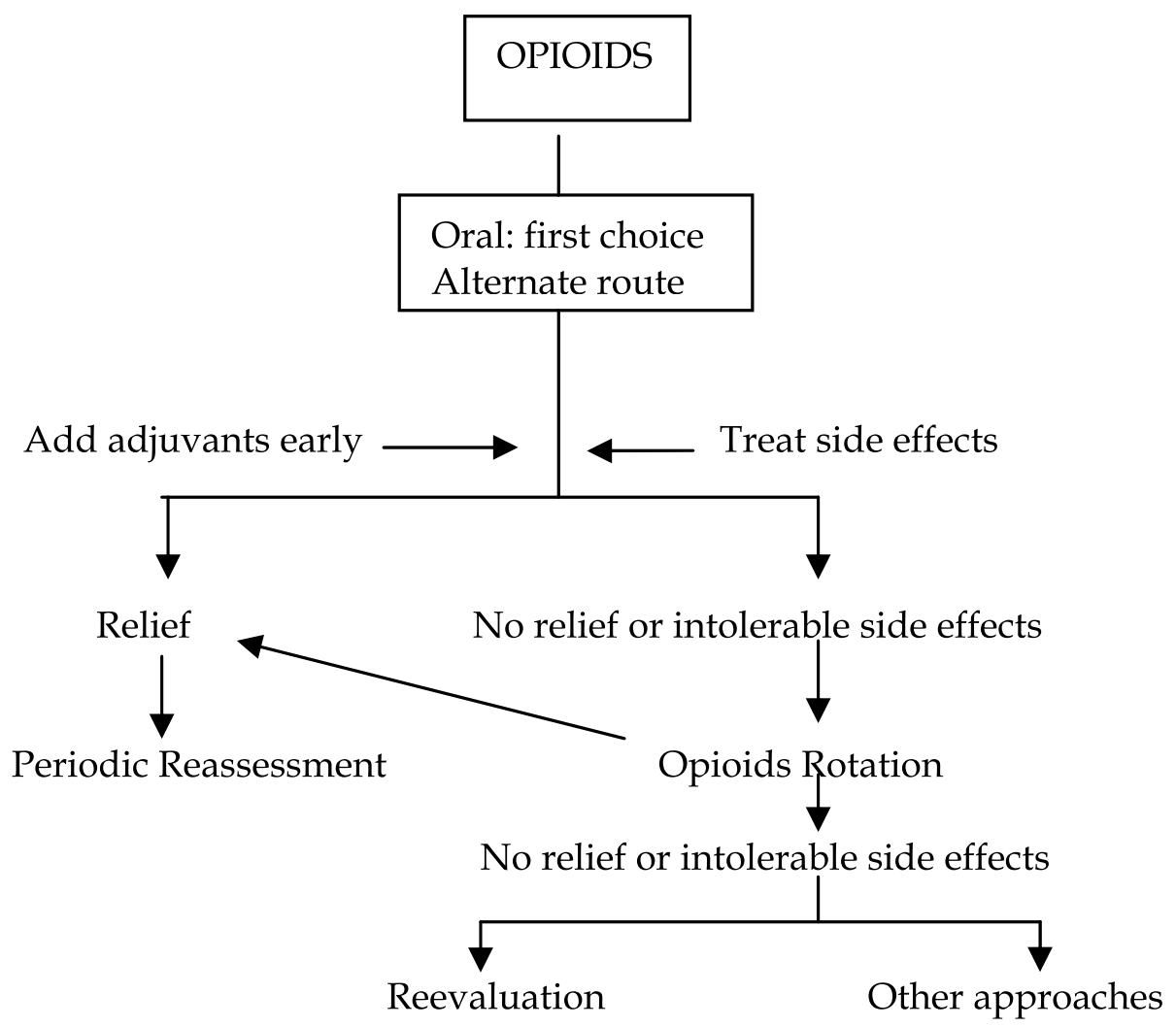

Fig. 7. Scheme of using opioid (Alanmanou, 2006a)

\subsubsection{Non-opioid analgesics}

Non-opioid analgesics are used singly in light pains or by combining with opioids in mild pains. The most frequent used non-opioids are paracetamol, aspirin and nonsteroid anti- 
inflammatory (Bedre\&Sethna, 2002; Golianu et al., 2000). Pharmacodynamic and pharmacokinetic features of paracetamol, salicylates and nonsteroid anti-inflammatory drug (NSAID) in children are not different from adults except for neonatal period. Drug selection changes depending on various factors such as action time of drug, whether asked for antiinflammatory effect or not, oral or IV route preference and adverse effects of drug. While majority of drugs in this group have both three of analgesic, antipyretic, anti-inflammatory effects, the others have just analgesic and antipyretic effects. Selections of analgesic are made in line with pain level according to step principle. According to WHO's three steps principle, nonsteroid anti-inflammatory drugs are given in light pains, weak opioids in addition to NSAIDs are given in mild pains, strong opioids are also given additionally in severe pains. Moreover, adjuvant drugs can be added in all steps (Eyigor et al., 2007). Schema related to using NSAIDs was given Fig. 8.

Acute and chronic pain of diverse etiologies

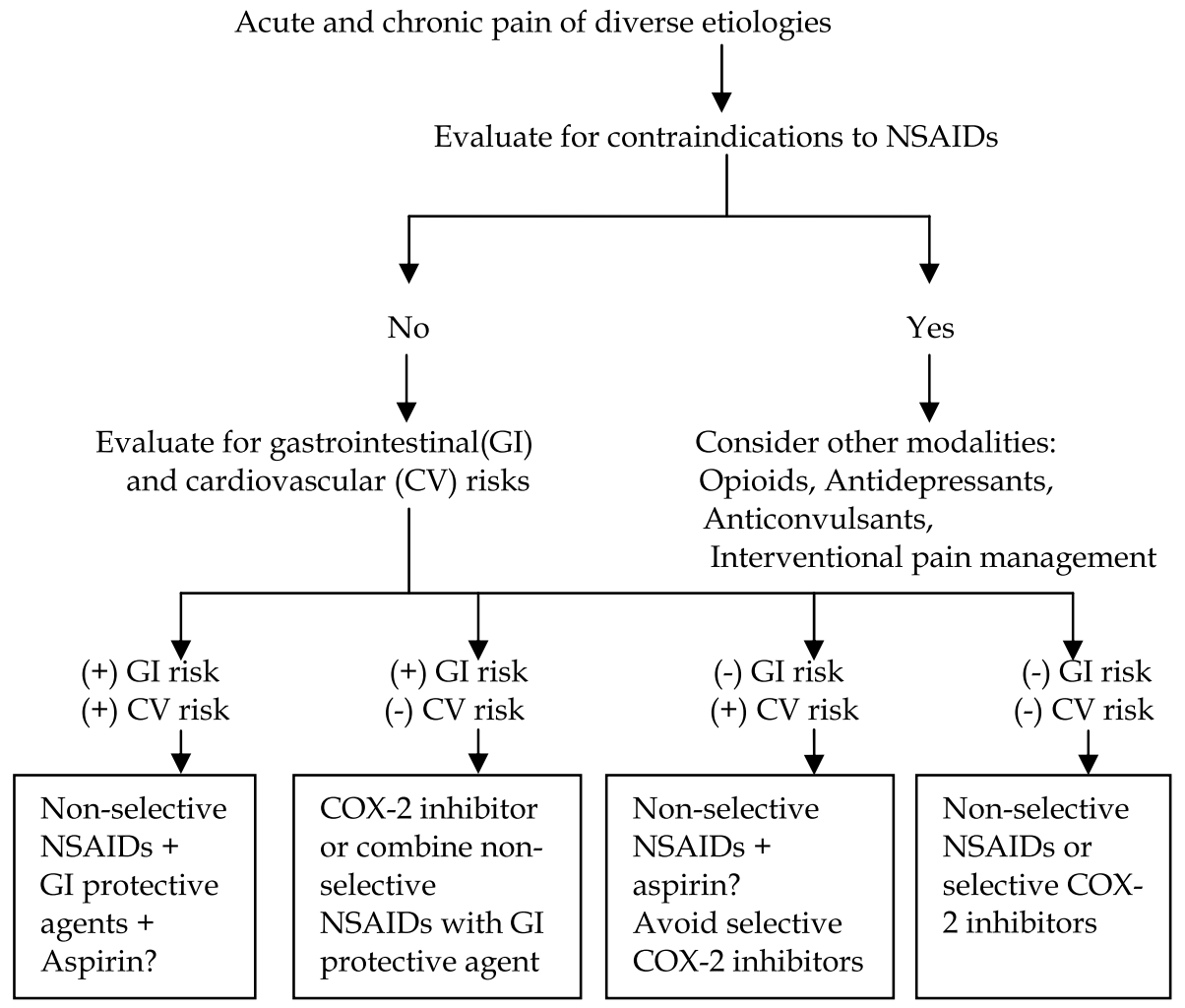

Fig. 8. Scheme of using nonsteroidal antiinflamatory drugs (Alanmanou, 2006b)

\subsubsection{Adjuvant agents}

Adjuvant analgesics are used for potantializing analgesic effects and improving symptoms accompanying pain. In this group, drugs such as anticonvulsants, antidepressants, oral local 
anesthetics, neuroleptics, myorelaxants, ntihistaminics, psychostimulants, corticosteroids and calcium channel blockers are used (Bedre\&Sethna, 2002, Eyigör et al., 2007). Unless drugs are useful in removing pain in children, invasive attempts might be applied. The fundamental reason for childhood regional anaesthesia and analgesia implementations' not attracting attention might be listed as lack of experience in this field, adverse effect fear and not establishing dialog with the patient during attempt. Anatomical differences such as being different heights and anatomical structures of children during adolescence, extension of dura and spinal cord to lower segments in newborn children, being tight of epidural field, not yet completing of myelination following the birth, being thin of ligaments and fascias might lead to technical difficulties in regional implementations (Yaster\&Hardart 2002; Desparment-Sheridan, 2000). Schema related to using steroids was given Fig. 9.

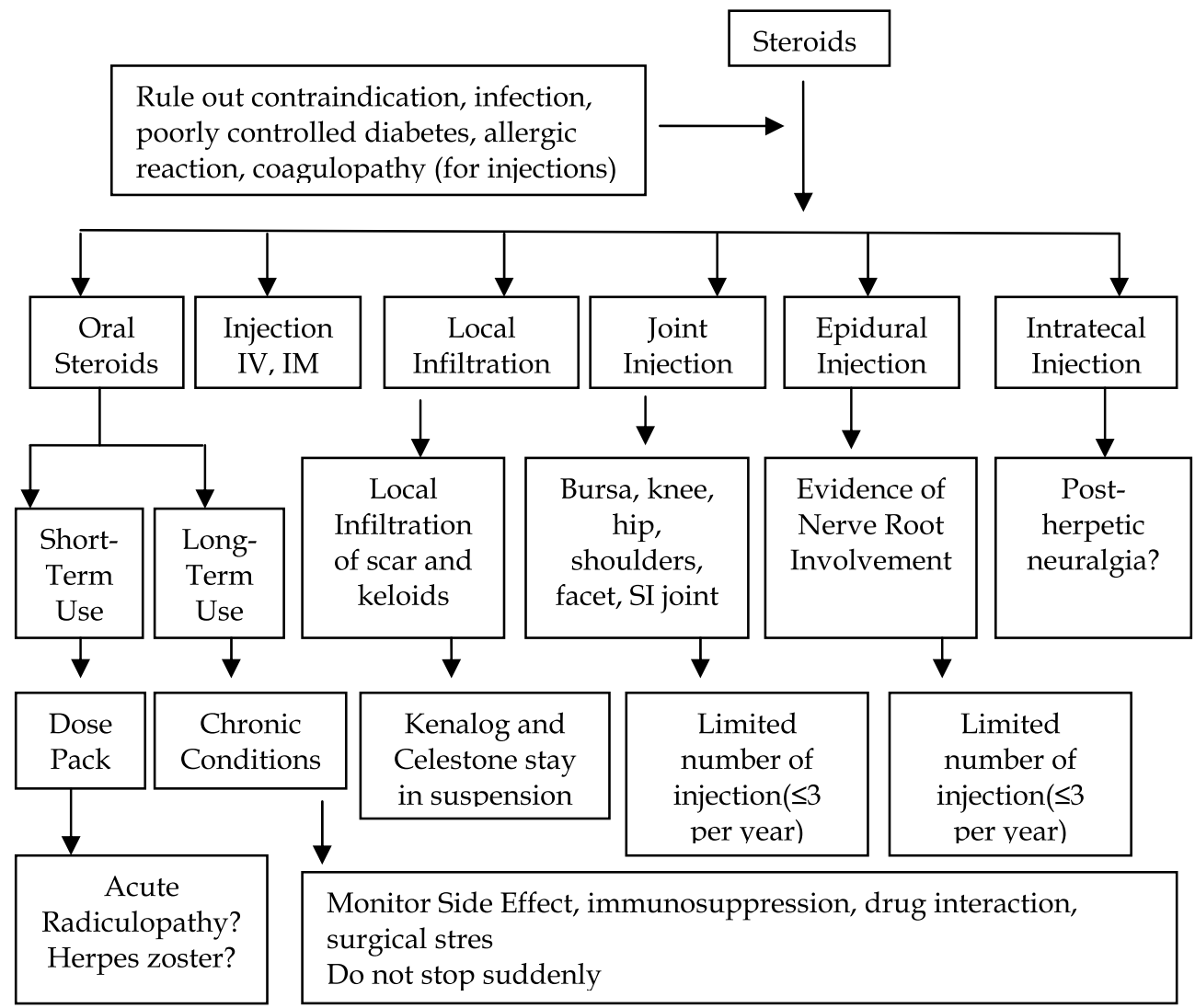

Fig. 9. Scheme of using steroids (Ramamurthy\&Alanmanou, 2006)

In general, pain assessment and treatment steps were given in fig. 10 . 


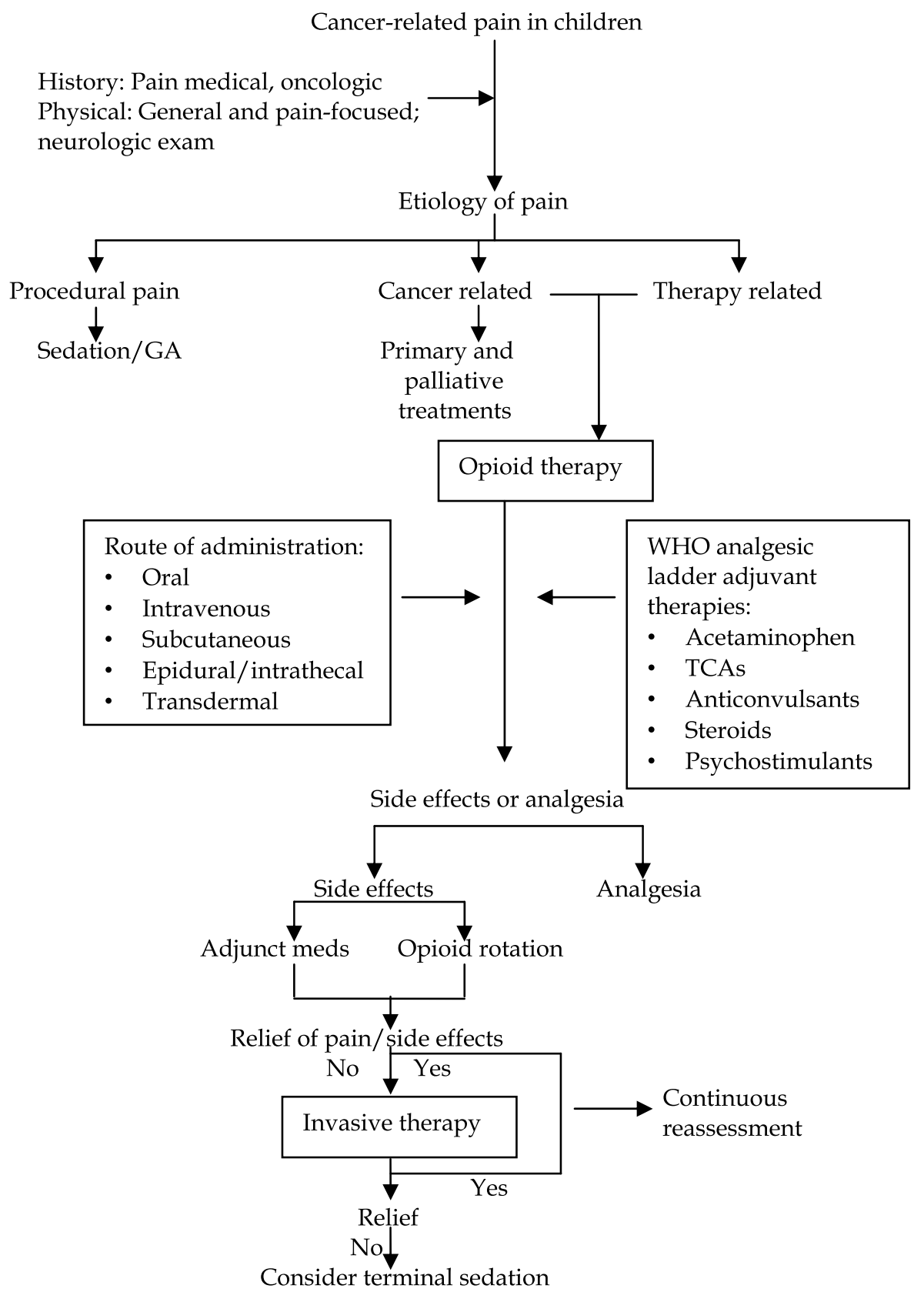

Fig. 10. Pain assessment and treatment practices (Weidner et al,. 2006) 


\subsection{Nonpharmacologic pain management}

Nonpharmacologic methods must be integral part of the management of children's cancer pain, beginning at the time of diagnosis and continuing throughout treatment (WHO, 1998). Nonpharmacologic methods in the management of pain have been found to be highly effective for some children and for some procedures. These techniques are easy to learn and should be used when possible to give the child some control in the management of pain. The examples given for distraction, muscle relaxation, and guided imagery are easy techniques to learn and can be used with young children (Hockenberry-Eaton, $\mathrm{M}$ et al; 1999). Non-drug approaches should supplement, but not replace, appropriate drug treatment (HockenberryEaton et al., 1999; WHO, 1998). In selection of nonpharmacologic method use, child's age, behavioral factors, coping ability, fear/anxiety and type of pain experience play role. Nonpharmacologic pain management implementations are divided into 4 groups as supportive, cognitive, behavioral and physical methods. In Table 6, non-pharmacologic methods used in relieving pain are summarized (WHO, 1998).

\begin{tabular}{|l|l|l|l|}
\hline Supportive & Cognitive & Behavioral & Physical \\
\hline $\begin{array}{l}\text { Family-centre } \\
\text { care }\end{array}$ & Distraction & Deep breathing & Touch \\
\hline Information & Music & Relaxation & Heat and cold ${ }^{*}$ \\
\hline Empathy & Imagery & & $\begin{array}{l}\text { Transcutaneous electrical } \\
\text { nerve stimulation (TENS) }\end{array}$ \\
\hline Choices & Hypnosis & & \\
\hline Play & & & \\
\hline
\end{tabular}

*Heat and cold should not be used with infants because of the risk of injury

Table 6. Nonpharmacologic methods of pain relief (WHO 1998)

\subsubsection{Supportive methods}

Supportive methods are intended to promote the good psychosocial care of children. The first principle is that care is family-centered, that is, it is based on the needs of both family and child. Parental involvement in decision-making, and in providing comfort to children, is particularly important. Parents need a perceptive environment and they may require instruction in how best to help their child. The family includes everyone who is intimately associated with the child. In most cases it is the parents who know their children best and can therefore become allies in treatment, but they may need to be taught how they can help manage their children's pain and anxiety. Family centered care encourages them to choose how to participate in treatment, giving them culturally appropriate information and teaching them coping techniques. It also helps family members to understand the cultural, spiritual, financial, social, interpersonal, and emotional impact of the diagnosis of cancer in a child.Making the clinic or hospital environment friendly to families is another important aspect of family-centre care, and liberal visiting arrangements and a physical atmosphere conducive to family participation in treatment should be encouraged. It is essential that a child's family and friends are made to feel welcome. Both children and families need information to prepare them for what will happen during the course of the disease end its treatment. If families are not accurately informed about the diagnosis and the treatment plan, they cannot participate. Information is accepted best if it is tailored to the needs of the 
child and family. Some children and families seek out information; others may find that too much information increases their anxiety. Health care provides should therefore try to individualize their dealings with families. An empathic approach is essential, and information should be given a little at a time, repeated as frequently as needed. Booklets, videos, drawings, and dolls can be useful tools in this process. Children should never be lied to about painful procedures; they will distrust and fear what will be done to them in the future. Health-care workers must be genuinely fond of children and know how to deal with them. Ideally, children should be given choices about which techniques to use to control pain. They should be given choices about which techniques to use to control pain. They should also be allowed to make decisions that do not interfere with treatment, such as which finger to prick for blood samples. Play is an essential part of every child's daily life and even the sickest child can be helped to play. Playing enables children to understand their world and to relax and forget their worries. All children must therefore have the time and place to play, and painful procedures must not be carried out in play areas. Normal activities such as school, hobbies, and visits by friends should be encouraged. Psychosocial treatment is an integral part of cancer pain treatment. It should be used in all painful or potentially painful situations, often combined with analgesic drug therapy (WHO, 1998).

\subsubsection{Cognitive methods}

Cognitive treatment methods are intended to influence a child's thoughts and images. Parents are often very skilled at using these methods because they know their children's preferences (WHO, 1998). Distraction is used to focus the child's attention away from the pain (Hockenberry-Eaton, 1999). Active distraction of children's attention is important: the more involved a child becomes in an activity, the greater the distraction from pain (WHO, 1998). For children, simple distraction techniques can be very effective in decreasing pain (Hockenberry-Eaton, M 1999). Infants and young children require concrete events or objects to attract their attention; interesting toys that provide something to see, hear, and do are best. Older children benefit from concentrating on a game, conversation, or special story (WHO 1998). In studies conducted, it was reported virtual reality was useful in distracting attention in painful medical interventions and decreasing pain and distress and child's selection should be attached importance in implementation (Gershon et al., 2004, Nilsson et al., 2009). Music, even as simple as a mother's lullaby, is a universal soother and distractor (WHO, 1998). Listening to music is an important tool which decreases heart rate, body temperature, blood pressure and breathing rate, distracts patient's attention, lowers the nausea depending on chemotherapy and especially increases the life quality of the patients in terminal period (Chase, 2003; Deng et al., 2004; Halstead\&Roscoe, 2002; Hiilliard, 2003; Kaminski\&Hall, 1996; Mccaffery, 2000). In a study performed by Burns et al. (2001) on cancer patients, it was reported that well-being and relaxion increased in the patients in music listening process, and tension decreased. In the study carried out by Chan et al. (2003) on the patients to whom colposcopy was applied, pain and anxiety level of the group listening to music was found lower. Nguyen et al. (2010) found that pain score, heart and breathing rate were lower in the group listening to music during and after lumbar puncture implementation in children with cancer. Listening to music was found to increase endorphin secretion by inducing alpha wands and to play a role in not only decreasing the pain by creating a state of relaxion but also in decreasing blood pressure, heart rate and 
other physiological responses (Henry, 1995). It is also quite important that child selects his/her own music (Nilsson S et al. 2009). Moreover, there are studies concerning influence of the music belonging to children's own culture (Balan et al., 2009; Ngyen et al. 2010). Imagery is the process in which a child concentrates on the image of a pleasant and interesting experience instead of on the pain. A child can be helped by an adult to become absorbed in a previous positive experience or an imaginary situation or adventure. Colors, sounds, tastes, smells and atmosphere can all be experienced in imagination (WHO, 1998; Hockenberry-Eaton, 1999). Storytelling is a powerful way to engage the imagination and provide distraction; children may enjoy old favorites or new stories told from books or from memory (WHO, 1998). What should be taken into account in assisted imagining is not to use images causing fear and anxiety in patient (such as water, forest) (Black\&Matassarin Jacobs, 1997). Children should be encouraged to use their imagination by their parents. In their studies in which Kuttner et al. (1988) compared medical treatment, occupation and imagination techniques under hypnosis during bone marrow aspiration, they found imagination method was more useful in children between 3-6, both occupation and imagination method was more effective in 7-10 group. Besides, it was determined that one or more sessions were required in order to learn coping abilities of the group to which occupation method was applied. Occupation methods which children may like according to their age groups are given in Table 7.

\begin{tabular}{|l|l|}
\hline Age & Methods \\
\hline 0-2 years & $\begin{array}{l}\text { Touching, stroking, patting, rocking, playing music, using mobiles over } \\
\text { the crib }\end{array}$ \\
\hline 2-4 years & Puppet play, storytelling, reading books, breathing, blowing bubbles \\
\hline 4-6 years & $\begin{array}{l}\text { Breathing, storytelling, puppet play, talking about favorite places, TV } \\
\text { shows, activities }\end{array}$ \\
\hline 6-11 years & $\begin{array}{l}\text { Music, breathing, counting, eye fixation, thumb squeezing, talking about } \\
\text { favorite places, activities on TV shows, humor }\end{array}$ \\
\hline
\end{tabular}

Table 7. Distraction techniques in children (Hockenberry-Eaton, M 1999)

True hypnosis requires specialized training, but pain can be modified by words of comfort and relief spoken in a particular way. Firstly, a child should be encouraged to relax and focus attention on a favorite activity, on deep breathing, or on a pain-free part of the body. Children can also imagine they are closing pain "switches" or "gates" or that they have the "magical" powers of their popular heroes to make their pain become less (WHO, 1998). Hypnotic ability is limited in children younger than 3, they begin at 5-6 and climb up to the highest level at 7-14. In the study conducted by Liossi et al (2006) on pediatric cancer patients, it was found that hypnosis decreased pain and anxiety level of the patients (Liossi et al., 2006). However, there are many clinic researches and systemic reviews concerning efficiency of hypnosis in decreasing distress related to chemotherapy and interventions (lumbar puncture, bone marrow aspiration, venepuncture etc.) which cause pain in especially pediatric cancer patients (Accardi\&Milling, 2009; Liossi et al., 2006, Liossi et al. 2009; Richardson et al., 2006; Rogovik\&Goldman, 2007; Tsao\&Zeltzer 2005; Zelter et al. 2001). Also, it was found that distress management implementations had useful and positive effect in coping with pain in the future (Rocha et al., 2009). Imagination scenes which children like are given in Table 8. 


\begin{tabular}{|l|l|l|}
\hline Visual Imagery & Auditory Imagery & Movement Imagery \\
\hline Favorite places & $\begin{array}{l}\text { Conversations with significant } \\
\text { others }\end{array}$ & Flying \\
\hline Animals & Favorite song & Swimming \\
\hline Flower gardens & Playing a musical instrument & Skating \\
\hline TV or movies & Listening to music & Amusement rides \\
\hline Favorite room & $\begin{array}{l}\text { Environmental sounds } \\
\text { (waves, etc.) }\end{array}$ & Any activity \\
\hline Favorite sport & & \\
\hline
\end{tabular}

Table 8. Favorite imagery scenes for children (Hockenberry-Eaton, M 1999)

\subsubsection{Behavioral methods}

Deep breathing is a simple way to help a child to reduce pain and gain self-control. It focuses the attention, reduces muscular tension, relaxes the diaphragm, and oxygenates the body. It is best to start teaching this technique by asking the child to breathe out, and tol et go of the tension, or "scary" feelings, with each breath. Deep breathing is the easiest technique to use with young children. Younger children can be taught to breathe deeply by blowing bubbles from soap solution or by using party blowers (WHO, 1998). For school age children, asking them to hold their breath during a painful procedure transfers their focus to their breathing and not on the procedure (Hockenberry-Eaton, 1999). Older children can use more sophisticated breathing techniques such as breathing in and out, each fort he count of three (WHO, 1998). Muscle relaxation Muscle relaxation is used to decrease mental and physical tension. It is used most effectively in older children and adolescents because it involves the relaxation of voluntary skeletal muscles. Slowly each muscle is tensed and then relaxed in a systematic way. Attention is placed on breathing which causes the individual to be aware of the feelings of tension and relaxation (Hockenberry-Eaton, 1999). Relaxation is often combined with suggestion and deep breathing, and these methods can reduce anticipatory anxiety and help to reduce nausea and vomiting (Hockenberry-Eaton, 1999; WHO, 1998). In the study Anderson et al. (2006) carried out on cancer patients, it was found that less pain was suffered in the group to which relaxion technique was applied. Walco et al (2005) reported significant decrease in heart rate using cognitive-behavioral method in preventing procedural distress in children with cancer. In systemic reviews of Ellis\&Spanos (1994), it was reported that cognitive-behavioral methods had critical importance in decreasing pain during painful procedures such as bone marrow aspiration and lumbar puncture. Cognitive-behavioral methods are the most frequently used methods to increase coping ability of the child and decrease children's distress in medical procedures (Collins et al., 2008).

\subsubsection{Physical methods}

Touch is important for all children, particularly the pre-verbal child, who understands the world to a large extent through touching and feeling. Touch must be appropriate for the child's needs, that is, not too invasive either physically or psychologically. Touching includes stroking, holding and rocking, caressing, massaging hands, back, feet, head, and stomach as well as swaddling. Vibration and tapping can also be comforting. When talking 
is too much effort for the child, touch can be the best form of communication. When a child must be touched for medical purposes, e.g. palpation of the abdomen, care must be taken to use warm hands, to proceed gently, and to talk quietly with the child about what is being done. Sources of heat and cold are often easily available. Ice wrapped in a cloth can be used to soothe disease pain or inflammation, or to reduce the pain of a procedure such as intramuscular injection. Heat is useful for muscle pain. However, neither cold nor heat should be used on infants because there is a risk of injury. The physical methods applied in removal of pain and their definitions are given in Table 9. Transcutaneous electrical nerve stimulation (TENS) is achieved with a battery-operated device that delivers electrical stimulation through electrodes placed on the skin. It possibly acts by cutaneous stimulation of large-diameter nerve fibres, reducing pain transmission at the spinal level. Children often experience TENS as tingling or tickling; it must not become painful. The technique is simple to use, is effective, and requires little preparation (WHO, 1998). Acupuncture has been used therapeutically in China for thousands of year, its importance in Europe and USA increases gradually. It was reported to be especially efficient in decreasing chemotherapy-related nausea/vomiting and cancer-related pain in the patients. However, number of studies carried out on pediatric patients is low (Hockenberry-Eaton, 1999; Jindal et al., 2008). In their study, Reindl et al. (2006) reported that acupuncture decreased the need of antiemetic treatment in preventing chemotherapy-related nausea in pediatric patients.. It is recommended to apply acupuncture with methods such as hypnosis and massage (Jindal et al 2008). Zelter et al (2002) applied hypnotherapy with acupuncture to children with chronic pain their study and reported no adverse effect, on the contrary parents and children reported significant improvements concerning pain and treatment. However, since there was no control group available in the study, efficiency of acupuncture / hypnotherapy was not specified.

\begin{tabular}{|l|l|}
\hline $\begin{array}{l}\text { Comfort } \\
\text { Measure }\end{array}$ & Description \\
\hline Massage & Includes stroking, rubbing or deep manipulation of muscles. \\
\hline Music & $\begin{array}{l}\text { Can help to provide the child with a familiar environment; children often } \\
\text { come to the hospital or hospice with their own music. }\end{array}$ \\
\hline Heat & $\begin{array}{l}\text { Warm compress or use of a heating pad, to the painful site (moist or dry } \\
\text { heat). }\end{array}$ \\
\hline Cold/Ice & $\begin{array}{l}\text { Cold compress or ice pack. Precaution: assure ice pack is wrapped allowing } \\
\text { comfortable sensation of cold without damaging the skin by freezing tissue. } \\
\text { Limit ice application to10 minutes, then rotate site. If skin becomes blanched, } \\
\text { discontinue cold treatment. }\end{array}$ \\
\hline
\end{tabular}

Table 9. Comfort measures (Hockenberry-Eaton, M 1999)

\section{Nursing approach}

As in all the other fields of pediatrics, supportive methods have indisputable importance in pediatric oncology. Family-centered care which is the fundamental element of supportive methods forms the integrative role of pediatric nursing. Parents should be encouraged to participate in care of their children at hospital in accordance with their readiness so that 
family-centered care implementations can be carried out and the care given should be controlled. Nurse training and consultancy roles should be used effectively. Parents should be allowed to ask question so that they could understand the diagnosis and treatment methods applied to their children and parents' opinion should be asked in decisions related to child's treatment. In this regard, nurse should encourage the parents to ask question and be open in communication with them. Pediatric nurse is responsible for training the parents about the care of the child. It is important that such training continues until child is discharged from the hospital. Nurse should make sure that family has gained the knowledge and skills required in respect of child's care and do these correctly. Nurse should prepare the parents about care of child at home by ensuring parents' participation in care and controlling the care they give at hospital (Boztepe, 2009). Nurses should conduct proper assessment and treatment of the pain which is a necessary part of children's care for optimal treatment of the child with pain. The pain which is not treated or taken under control might lead to long-term chronic pain. Having limited knowledge about effective assessment and treatment options might be a reason for being unable to take the pain under control. However, attitude, belief and previous experiences may affect their decisions. Nurses should spare time for themselves in order to equip themselves with up-to-date knowledge concerning assessment and treatment of the pain (Clark, 2011). Nurses play a critical role in efficient pain management of the patient. Nurse should permanently inform the patient and patient's family about pain management methods. They should be encouraged to participate in efficient pain management and trained about how pain management and methods to increase their life qualities will be (Williams, 2011). Also, nurses should ensure inclusion of effective behavioral methods in routine care of the children with cancer (McCarthy et al., 1996). Pain is a subjective experience and each and every child should be treated as an individual. Multimodal approach (together with pharmacologic and nonpharmacologic pain management) is the best way to optimize pain control with least negative effects. Even the smallest children deserve ensuring the best pain control in a safe manner (Clark, 2011).

\section{References}

Accardi, M.\&Milling L.S. (2009) The effectiveness of hypnosis for reducing procedurerelated pain in children and adolescents: a comprehensive methodological review. Journal of Behavioral Medicine, Aug;32(4), pp. 328-39. ISSN (printed): 0160-7715.

Alanmanou, E. (2006a). Opioids. In: Decision making in pain management. Somayaji Ramamurthy, Euleche Alanmanou, James Rogers, (Ed.). pp. 255, 2nd Edition, Elsevier Mosby, ISBN 13: 978-0-323-01974-3

Alanmanou, E. (2006b). Nonsteroidal antiinflamatory drugs. In: Decision making in pain management. Somayaji Ramamurthy, Euleche Alanmanou, James Rogers, (Ed.). pp. 247, 2nd Edition, Elsevier Mosby, ISBN 13: 978-0-323-01974-3

Anderson, K.O., Cohen, M.Z., Mendoza, T.R., Guo, H., Harle, M.T. et al. (2006). Brief cognitive-behavioral audiotape interventions for cancer-related pain: Immediate but not long-term effectiveness. Cancer, 107(1), pp.207-214, ISSN 1097-0142

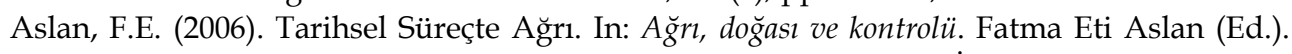
Avrupa Tıp Kitapcılık Ltd. Şti, pp. 3-9, ISBN 975-6257-17-2, İstanbul 
Balan, R., Bavdekar, S. B., \& Jadhav, S. (2009). Can Indian classical instrumental music reduce pain felt during venepuncture? Indian Journal of Pediatrics, 76, pp. 469-473. ISSN 0019-5456

Bedre, C.B. \& Sethna, N.F.(2000). Analgesics for the treatment of pain in children. The New England Journal of Medicine Vol. 347, pp. 1094- 1103 ISSN 0028-4793

Bial, E. \& Cope, D.K. (2011). Introduction to pain management, historical perspectives, and careers in pain management. In: . In: . Essentials of pain management. Naili Vadivelu, Richard D. Urman \& Roberta L. Hines (Ed.). Springer Science+Business Media. pp. 3-7, ISBN 978-0-387-87578-1 New York.

Black, J.M.\&Matassarin Jacobs, E. (1997). Pain, In: Medical Surgical Nursing: clinical management for continuity of care, Thomas Eoyang (Ed) 5. edition, W.B. Saunders Company, pp: 342-365, ISBN 9780721663999, Philadelphia

Boztepe, H. (2009), Family Centered Care in Pediatric Nursing: Review, Turkiye Klinikleri Journal of Nursing, 1(2). pp. 88-93, ISSN: 1308-092X

Bucher, J.A., Trostle, G.B. \& Moore, M. (1999). Family reports of cancer pain, pain relief, and prescription access. Cancer Practice, Vol. 7, No.2, pp.71-77, ISSN 1065-4704

Burns, S.J.I., Harbuz, M.S., Hucklebridge, F. \& Bunt, L. (2001). A pilot study into the therapeutic effects of music therapy at a cancer help center, Alternative Therapies in Health and Medicine, 7(1), pp. 48-56. ISSN 1078- 6791

Chan, Y.M., Lee, P.W., Ng TY Ngan, H.Y.\&Wong, L.C. (2003). The use of music to reduce anxiety for patients undergoing colposcopy: a randomized trial, Gynecologic Oncology, 9(1), pp. 213-217. ISSN 0090-8258

Chase, K.M. (2003). Multicultural music therapy: a review of literature, Music Therapy Perspectives, 21(2), pp. 84-88. ISSN: 0734-6875.

Chiu, T.Y.; Hu, W.Y. \& Chen, C.Y. (2000). Prevalence and severity of symptoms in terminal cancer patients: a study in Taiwan. Support Care in Cancer, Vol. 8, No.4, pp. 311313, ISSN 0941-4355

Cizmeci, P. \& Babacan, A.(2007). Analjezikler ve Analjezik Kullanım İlkeleri. Clinic Medicine. (Pain Special Issue -2), pp. 9-14

Clark, L, (2011) Pain management in the pediatric population, Critical Care Nursing Clinics of North Americais 23, pp. 291-301

Collins, J.J., Stevens, M.M., Berde, C.B. (2008) Pediatric cancer pain, In: Clinical Pain Management, Cancer Pain, Andrew Rice (Ed) 2nd edition, Hodder \& Stoughton Limited, pp: 345-355, London

Dedeli, Ö. \& Karadeniz, G. (2009). Kanser ağrısının kontrolü ile psikososyal-spiritüel modelin birleştirilmesi, A ğrı, Vol. 21, No. 2, pp. 45-53, ISSN 1300-0012

Deng, G., Cassileth, B.R. \& Yeung, K.S. (2004). Complementary therapies for cancer-related symptoms, Journal of Support Oncology, 2(5), pp. 427-429.

Desparmet- Sheridan, J.F. (2000). Pain in Children, In: Practical Management of Pain, PP Raj (Ed.), Mosby, ABD, pp. 295-315

Eidelman, A. \& Carr, D.B. (2006). Taxonomy of Cancer Pain. In: Cancer Pain: Pharmacologic, intervention, and palliative approaches. De Leon-Casasola, O.A. (Ed.). Elsevier Inc. pp. 3-6 
Ellis, J.A. \& Spanos, N.P. (1994). Cognitive-behavioral interventions for children's distress during bone marrow aspirations and lumbar punctures: a critical review. Journal of Pain and Symptom Management, Feb;9(2), pp. 96-108. ISSN: 0885-3924

Eyigör, C.; Pirim, A. \& Uyar, M. (2007). Çocuklarda Ağrı Tedavisi. Clinic Medicine. (Pain Special Issue -2), pp. 15-22.

Gershon, J., Zimand, E., Pickering, M., Rothbaum, B.O., \& Hodges, L. (2004). A pilot and feasibility study of virtual reality as a distraction for children with cancer. Journal of the American Academy of Child and Adolescent Psychiatry, Oct;43(10), pp. 1243-9 ISSN:0890-8567

Gingrich, T. (2006). Medical management of cancer pain. In: Decision making in pain management. Somayaji Ramamurthy, Euleche Alanmanou, James Rogers, (Ed.). pp. 127, 2nd Edition, Elsevier Mosby, ISBN 13: 978-0-323-01974-3

Golianu, B., Krane, E.J., Galloway, K.S. \& Yaster, M. (2000). Pediatric acute pain management. Pediatric Clinics of North America, Vol.47, No.3, pp. 559-587, ISSN 0031-3955

Halstead, M.T. ve Roscoe, S.T. (2002). Restoring the spirit at the and of life: music as an intervention for oncology nurses, Clinical Journal of Oncol Nursing, 6(6), pp. 332- 336. ISSN: $1462-3889$

Helms, J.M. (1998). An overview of medical acupuncture. Altern Ther. (May). Vol. 4, No.3 , pp. $32-45$

Henry, L.L. (1995). Music therapy: a nursing intervention for the control of pain and anxiety in the ICU: a review of the research literature, Dimension Critical Care Nursing, 14(6), pp. 295-304, ISSN: 1538-8646

Higginson, I.J. \& Murtagh, F. (2010). Cancer pain epidemiology. In: Cancer Pain Assessment and Management. Eduardo D. Bruera, Russell K. Portenoy (Ed.). Second edition. Cambridge University Press. pp. 37-52, ISBN 0521 77332 6, USA

Hiilliard, R.E. (2003). The effect of music therapy on the quality and length of life people diagnosed with terminal cancer, Journal of Music Therapy, 40(2), pp. 113-117. ISSN: 0022-2917

Hockenberry-Eaton, M.; Barrera, P.; Brown, M.; Bottomley, S.J. \& O’Neill, J.B. (1999). Pain management in children with cancer. Texas Cancer Council. pp. 9-25, 50-54, Texas

Jindal, V., Ge, A.,\&Mansky, P.J. (2008). Safety and Efficacy of Acupuncture in Children A Review of the Evidence. Journal of Pediatric Hematology/ Oncology. June; 30(6), pp. 431-442. ISSN: 1077-4114

Kaminski, J. \& Hall, W. (1996). The effect of soothing music on neonatal behavioral states in the hospital newborn nursery, Neonatal Network, 25(1), pp. 45-54. ISSN 0730-0832

Krauss, B. \& Gren, S.M. (2000). Sedation and analgesia for procedures in children. The New England Journal of Medicine. Vol. 342:, pp. 938-945, ISSN 0028-4793

Kuttner, L., Bowman, M. \& Teasdale, M. (1988). Psychological treatment of distress, pain, and anxiety for young children with cancer. Journal of Developmental and Behavioral Pediatrics. 9, pp. 374-81.

Liossi, C., White, P. \& Hatira, P. (2006). Randomized clinical trial of local anesthetic versus a combination of local anesthetic with self-hypnosis in the management of pediatric procedure-related pain. Health Psychology, 25(3), pp. 307-315. 
Liossi, C., White, P. \& Hatira, P. (2009). A randomized clinical trial of a brief hypnosis intervention to control venepuncture-related pain of paediatric cancer patients. Pain. Apr;142(3), pp. 255-63

Manworren , R.C.B. \& Hynan, L.S. (2003). Clinical Validation of FLACC: Preverbal patient pain scale. Pediatric Nursing, Vol.29, pp. 140-146. ISSN 1744-6155

Mccaffery, R.G. (2000). The lived experience of listening to music while recovering from surgery. Journal of Holistic Nursing, 18(4), pp. 378-390. ISSN 0898-0101

McCarthy, A.M., Cool, V.A., Petersen, M., \& Bruene, D.A. (1996). Cognitive behavioral pain and anxiety interventions in pediatric oncology centers and bone marrow transplant units. Journal of Pediatric Oncology Nursing. Jan;13(1), pp. 3-12; discussion 13-4. ISSN 1043-4542

McGrath, P.A. \& Crawford, E.J. (2010). Evaluating pain for children with cancer. . In: Cancer Pain Assessment and Management. Eduardo D. Bruera, Russell K. Portenoy (Ed.). Second edition. Cambridge University Press. pp. 131, ISBN 052177332 6, USA

Mirchandani, A., Saleeb, M. \& Sinatra, R. (2011). Acute and Chronic Mechanisms of Pain. In: Essentials of pain management. Nalini Vadivelu, Richard D. Urman, \& Roberta L. Hines, (Ed.). Springer Science+Business Media. pp. 45-48, ISBN 9780387875781, New York

Nguyen, T.N., Nilsson, S., Hellström, A.L., \& Bengtson, A. (2010). Music therapy to reduce painand anxiety in children with cancer undergoing lumbar puncture: A randomized clinical trial, Journal of Pediatric Oncology Nursing, 27, pp. 146-155, ISSN $1043-4542$

Nilsson, S., Finnstrom, B., Kokinsky, E., \& Enskar, K. (2009). The use of virtual reality for needle-related procedural pain and distress in children and adolescents in a paediatric oncology unit. European Journal of Oncology Nursing, 13, pp. 102-109, ISSN 1462-3889

Nilsson, S., Kokinsky, E., Nilsson, U., Sidenvall, B., \& Enskar, K. (2009). School-aged children's experiences of postoperative music medicine on pain, distress, and anxiety. Paediatric Anaesthesia, 19, pp. 1184-1190. ISSN 1155-5645

O'leary, N.; Stone, C. \& Lawlor, P.G. (2010). Multidimensional assessment: pain and palliative care. . In: Cancer Pain Assessment and Management. Eduardo D. Bruera, Russell K. Portenoy (Ed.). Second edition. Cambridge University Press. pp. 110, ISBN 052177332 6, USA

Plotnick, A.B., \& O'Grady G.J. (1991). Hypnotic responsiveness in children. In: Clinical hypnosis with children, William C. Wester, Donald J. O'Grady (Ed), Brunner/Mazel, pp. 19-33. New York

Portenoy, R.K. \& Kanner, R.M. (1996). Definition and assessment of pain. In: Pain management: Theory and Practice. F.A. Davis (Ed.). Company, Philadelphia, pp. 3-17

Potter, J., Hami, F., Bryan, T. \& Quigley, C. (2003). Symptoms in 400 patients referred to palliative care services: prevalence and patterns. Journal of Palliative Medicine, Vol.17, pp. 310-314, ISSN 1096-6218

Ramamurthy, S. \& Alanmanou, E. (2006). Steroids. In: Decision making in pain management. Somayaji Ramamurthy, Euleche Alanmanou, James Rogers, (Ed.). pp. 249, 2nd Edition, Elsevier Mosby, ISBN 13: 978-0-323-01974-3 
Reindl, T., Geilen, W., Hartmann, R., Wiebelitz, K.R., Kan, G., Wilhelm, I., Lugauer, S., Behrens, C., Wieberlenn, T., Hasan, C., Gottschling, S., Wild-Bergner, T., Henze, G., \& Driever, P.H. (2006). Acupuncture against chemotherapy-induced nausea and vomiting in pediatric oncology. Interim results of a multicenter crossover study. Support Care in Cancer, 14, pp. 172-176. ISSN 1433-7339

Richardson, J., Smith, J.E., McCall, G., \& Pilkington, K. (2006). Hypnosis for procedurerelated pain and distress in pediatric cancer patients: a systematic review of effectiveness and methodology related to hypnosis interventions. Journal of Pain and Symptom Management. 31, pp. 70-84. ISSN 0885-3924

Rocha, E. M., Marche, T. A., \& von Baeyer, C.L. (2009). Anxiety influences children's memory for procedural pain. Pain Research \& Management, 14(3), pp. 233-237. ISSN 1203-6765

Rogovik, A.L. \& Goldman, R.D. (2007). Hypnosis for treatment of pain in children, Canadian Family Physician, 53, pp. 823-25, ISSN: 0008-350X

Steggles, S., Damore-Petingola, S., Maxwell, J. \& Lightfoot, N. (1997). Hypnosis for children and adolescents with cancer: an annotated bibliography, 1985-1995. American Journal of Clinical Hypnosis. 39, pp. 187-200, ISSN 0002-9157

Tranmer, J.E., Heyland, D., Dudgeon, D., Groll, D., Squires-Graham, M. \& Coulson, K. (2003) Measuring the symptom experience of seriously ill cancer and noncancer hospitalized patients near the end of life with the Memorial Symptom Assessment Scale. Journal of Pain and Symptom Management, Vol. 25, No.5, pp. 420-429, ISSN 0885-3924

Tsao, J.C.I. \& Zeltzer, L.K (2005). Complementary and Alternative Medicine Approaches for Pediatric Pain: A Review of the State-of-the-science, Evidence-Based Complementary and Alternative Medicine (eCAM), 2(2), pp. 149-159

Unuvar, A. (2009). Ağrı. In: Pediatrik Onkoloji. Alp Özkan (Ed. ). Nobel Medical Kitabevleri. pp. 1267-1271, ISBN 9789754206630, İstanbul

Walko, G.A., Conte, P.M., Labay, L.E., Engel, R., \& Zeltzer LK, (2005) Procedural distress in children with cancer: self-report, behavioral observations, and physiological parameters. The Clinical Journal of Pain. 21(6), pp. 484-90, ISSN 1536-5409

Weidner, N.J.; Goldschneider, K.R. \& Varughese ,A.M. (2006). Cancer-Related Pain in Children. In: Decision making in pain management. Somayaji Ramamurthy, Euleche Alanmanou, James Rogers, (Ed.). pp. 235, 2nd Edition, Elsevier Mosby, ISBN 13: 978-0-323-01974-3

Williams, E. (2011). Nursing perspective on pain management, In: Essentials of pain management. Nalini Vadivelu, Richard D. Urman, \& Roberta L. Hines, (Ed.). Springer Science+Business Media. pp. 374, ISBN 9780387875781, New York

World Health Organization (1998), Cancer Pain Relief and Palliative Care in Children, Geneva, pp:18-22

Yaster, M. \& Hardart, R.A. (2002). Pediatric pain management. In: Text book of Regional Anesthesia. P. Prithvi Raj (Ed.). Churchill Livingstone, pp. 1009-1032. ABD

Yun, Y.H., Heo, D.S., Lee, I.G., Jeong, H.S., Kim, H.J., Kim, S., Kim, Y.H., Ro, Y.J., Yoon, S.S., Lee, K.H. \& Huh, B.Y. (2003). Multicenter study of pain and its management in 
patients with advanced cancer in Korea. Journal of Pain and Symptom Management, Vol.25, No.5, pp. 430-437, ISSN 0885-3924

Zeltzer, L.K., Dolgin, M.J., LeBaron, S., \& LeBaron, C. (1991). A randomized, controlled study of behavioral intervention for chemotherapy distress in children with cancer. Pediatrics. 88, pp. 34-42. ISSN 0031-4005

Zeltzer, L.K., Tsao, J.C.I., Stelling, C., Powers, M., Levy, S., \& Waterhouse, M. (2002). A phase I study on the feasibility of an acupuncture/hypnotherapy intervention for chronic pediatric pain. Journal of Pain and Symptom Management, 24, pp. 437-46. , ISSN 0885-3924 


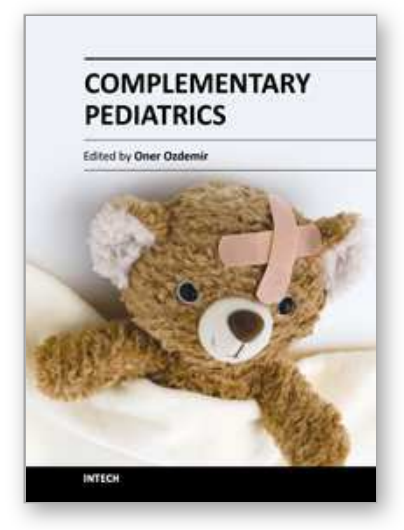

\author{
Complementary Pediatrics \\ Edited by Dr. Öner Özdemir
}

ISBN 978-953-51-0155-0

Hard cover, 354 pages

Publisher InTech

Published online 16, March, 2012

Published in print edition March, 2012

Complementary Pediatrics covers complementary issues of pediatric subspecialties consisting of ophthalmologic, surgical, psychosocial and administrative issues of frequently used medications. This book volume with its 16 chapters will help get us and patients enlightened with the new developments on these subspecialties' area.

\title{
How to reference
}

In order to correctly reference this scholarly work, feel free to copy and paste the following:

Nejla Canbulat and Ayşe Sonay Kurt (2012). Pain Management and Nursing Approaches in Pediatric Oncology, Complementary Pediatrics, Dr. Öner Özdemir (Ed.), ISBN: 978-953-51-0155-0, InTech, Available from: http://www.intechopen.com/books/complementary-pediatrics/pain-management-and-nursingapproaches-in-pediatric-oncology

\section{INTECH}

open science | open minds

\author{
InTech Europe \\ University Campus STeP Ri \\ Slavka Krautzeka 83/A \\ 51000 Rijeka, Croatia \\ Phone: +385 (51) 770447 \\ Fax: +385 (51) 686166 \\ www.intechopen.com
}

\author{
InTech China \\ Unit 405, Office Block, Hotel Equatorial Shanghai \\ No.65, Yan An Road (West), Shanghai, 200040, China \\ 中国上海市延安西路65号上海国际贵都大饭店办公楼405单元 \\ Phone: +86-21-62489820 \\ Fax: +86-21-62489821
}


(C) 2012 The Author(s). Licensee IntechOpen. This is an open access article distributed under the terms of the Creative Commons Attribution 3.0 License, which permits unrestricted use, distribution, and reproduction in any medium, provided the original work is properly cited. 